\title{
EVALUATING AN ESP TEXTBOOK: A CASE STUDY OF ENGLISH FOR BANKING PURPOSES AT EDBI
}
AVALIANDO UM LIVRO DIDÁTICO DO ESP: UM ESTUDO DE CASO DE INGLÊS PARA FINS BANCÁRIOS NO EDBI

EVALUACIÓN DE UN LIBRO DE TEXTO ESP: UN ESTUDIO DE CASO DE INGLÉS PARA FINES BANCARIOS EN EDBI

\author{
Mohammad-reza Takrousta ${ }^{1}$ \\ Parviz Behrouzi² \\ Sholeh Kolahi ${ }^{3}$
}

\begin{abstract}
An English language textbook for banking purposes had been designed based on the language needs of EDBI staffs. Consequently, an English course for banking purposes was held at EDBI using the designed book. To ensure about the validity and quality of the textbook, it was evaluated by 2 language experts through an interview before the course and 30 bank's staffs as the learners through a set of questionnaire after the course. Based on the quantitative and qualitative findings of the study, both language experts and EDBI's staffs had positive attitudes toward the materials, topics, activities and tasks, language skills and physical appearance of the text book and recognized it relevant to their language needs. However, they asked for some modifications such as edition of misspelling and ungrammatical use of some sentences and additions of new materials such as a glossary and business and banking correspondences to the existing ones. The results of the study became a basis to further improvement and correction until the draft would be finalized as a ready use material. Therefore, some modifications and alternations were conducted based on their evaluations to make the product more valid and more practical. The findings of the present research bear significant implications for materials developers and teachers especially in applying appropriate materials in ESP courses and evaluating the textbooks in the related studies.
\end{abstract}

Key words: ESP (English for Specific Purposes), Textbook Evaluation, EDBI (Export Development Bank of Iran), bank's staffs

Resumo: Um livro didático em inglês para fins bancários foi elaborado com base nas necessidades de idioma das equipes da EDBI. Consequentemente, um curso de inglês para fins bancários foi realizado no EDBI usando o livro projetado. Para garantir a validade e a qualidade do livro, ele foi avaliado por dois especialistas em idiomas por meio de uma entrevista antes do curso e por 30 funcionários do banco

\footnotetext{
${ }^{1}$ Islamic Azad University, Tehran, Iran.

${ }^{2}$ Islamic Azad University, Tehran, Iran.

${ }^{3}$ Islamic Azad University, Tehran, Iran.
} 
como alunos, por meio de um conjunto de questionários após o curso. Com base nas descobertas quantitativas e qualitativas do estudo, os especialistas em idiomas e as equipes da EDBI tiveram atitudes positivas em relação aos materiais, tópicos, atividades e tarefas, habilidades linguísticas e aparência física do livro e o reconheceram relevante para suas necessidades de idioma. No entanto, eles pediram algumas modificações, como edição de erros de ortografia e uso gramatical de algumas frases e acréscimos de novos materiais, como glossário e correspondências comerciais e bancárias às existentes. Os resultados do estudo se tornaram uma base para melhorias e correções adicionais, até que o rascunho fosse finalizado como um material pronto para uso. Portanto, algumas modificações e alternâncias foram realizadas com base em suas avaliações para tornar o produto mais válido e mais prático. Os resultados da presente pesquisa têm implicações significativas para os desenvolvedores e professores de materiais, especialmente na aplicação de materiais apropriados nos cursos de PES e na avaliação dos livros didáticos nos estudos relacionados.

Palavras-chave: ESP (inglês para fins específicos), avaliação de livros didáticos, EDBI (Banco de Desenvolvimento de Exportações do Irã), funcionários do banco

Resumen: Se diseñó un libro de texto en inglés para fines bancarios basado en las necesidades lingüísticas del personal de EDBI. En consecuencia, se realizó un curso de inglés con fines bancarios en EDBI utilizando el libro diseñado. Para garantizar la validez y la calidad del libro de texto, fue evaluado por 2 expertos en idiomas a través de una entrevista antes del curso y el personal de 30 bancos como estudiantes a través de un cuestionario después del curso. Con base en los hallazgos cuantitativos y cualitativos del estudio, tanto los expertos en idiomas como el personal de EDBI tenían actitudes positivas hacia los materiales, temas, actividades y tareas, habilidades lingüísticas y apariencia física del libro de texto y reconocieron que era relevante para sus necesidades lingüísticas. Sin embargo, solicitaron algunas modificaciones, como la edición de errores ortográficos y el uso no gramatical de algunas oraciones y la adición de nuevos materiales, como un glosario y correspondencias comerciales y bancarias a las existentes. Los resultados del estudio se convirtieron en una base para una mayor mejora y corrección hasta que el borrador se finalice como un material listo para usar. Por lo tanto, se realizaron algunas modificaciones y alternancias basadas en sus evaluaciones para hacer que el producto sea más válido y más práctico. Los hallazgos de la presente investigación tienen implicaciones significativas para los desarrolladores y maestros de materiales, especialmente en la aplicación de materiales apropiados en los cursos ESP y en la evaluación de los libros de texto en los estudios relacionados.

Palabras clave: ESP (inglés para fines específicos), Evaluación de libros de texto, EDBI (Export Development Bank of Iran), personal del banco

\section{INTRODUCTION}

The textbook has an outstanding role in teaching and learning English especially for specific purposes. Therefore, they should serve the English course in the best way. According to McGrath (2006), "course books tend to dictate what is taught, in what order and, to some extent, how and what learners learn". He believes that textbooks are the most significant part of learning and teaching process and evaluating textbooks as one of the most important tasks to the future success of programs. Textbooks are commodities, political objects, and cultural representations and, therefore, are the results of struggles and compromise in order to 
determine how and by whom they will be produced, how and by whom their contents will be selected, how and to whom they will be distributed, and how teachers and students will make use of them(Shannon, 2010). Meantime, the term evaluation has been repeatedly used in education and it is often defined as a process of inquiry in which data are collected through different instruments and from different sources. Program evaluation, according to Kiely (2009), is a form of inquiry which describes the achievement of a given programme, provides explanations for these, and sets out ways in which further development might be realized (Niely, 2009:99). Like program evaluation, textbook evaluation, "involves measuring the value or (potential value) of a set of learning materials by making judgments about the effect of the materials [textbook] on the people using them" (Tomlinson \& Masuhara 2004). Moreover, Richards and Renandy (2002) states that materials evaluation [textbooks] is worth doing as it helps us identify the strengths and weakness of the materials.

In spite of the fact that textbooks are a significant factor in most of EFL classes, there has been little investigation done in terms of how and why materials are selected by teachers. In the related studies, Baleghizadeh and Rahimi (2011) indicated that the systematic evaluation of textbooks was not often conducted and students' requirements and opinions concerning the materials developed for them were neglected in Iran. Likewise, Eslami-Rasekh (2010) pointed out that ESP textbooks developed for the students of engineering by the Ministry of Higher Education in Iran was not born out of any systematic needs analysis. In another study done by Amirian and Tavakoli (2009), they assessed and evaluated the elements of ESP textbooks for engineering students. They reported that ESP courses had been useful and successful in making background knowledge on terminology and reading proficiency of that specific field in the minds of future engineers.

In recent years, some attentions have been made to ESP course design and evaluation. Export development bank of Iran as the only Exim bank of Iran, which specifically deals with international banking affairs, made special attention to this issue. In comprehensive investigations, they found that the current available books in the market were not enough for training their staffs. Thus, the researchers of this study who were both language experts and bank's employees were asked to design an English course specifically for bank's staffs. The researchers designed the required textbook based on a need analysis from staffs of this bank. However, both the designers of the textbook as well as banks administrative were well aware that the validity of such a textbook would be ensured if an evaluation would be made in this regard. Therefore, the aim of this study is to see whether the language experts and EDBI's staffs as the learners of the course approve the quality of the designed book. To this end, the following research questions are posted in order to achieve the objectives of the study.

RQ1. How do language experts and EDBI's staffs assess the quality of the book?

RQ2. What recommendations do language experts and EDBI's staffs make for improvement of the textbook? 


\section{LITERATURE REVIEW}

\subsection{Textbook Evaluation}

Textbook evaluation is an attempt to measure the potential value of textbooks (Tomlinson, 2011). It involves making judgments about the effects of textbooks on people (learners, instructors and administrators) who use them. These effects may be measured through such features as the: credibility, validity, flexibility, etc. of the textbook.

Textbook evaluation plays an important role in the process of teaching and learning as it can uncover the strengths and weaknesses of textbooks in general, and their relevance to a specific context in particular. It helps teachers understand the textbook so that they can amend their teaching to suit the course aims, and learners' needs. According to Awasthi (2006) and Tomlinson (2003), the selection of textbooks usually involves a process of textbook evaluation. It can also make student and teachers aware of important features to look for in textbooks. It provides them with information about evaluation criteria to help them to become more critical of a wide range of published textbooks (Litz, 2002).

\subsection{Approaches and Criteria for Textbook Evaluation}

Textbook evaluation is a complex matter, as there are many variables, which may affect the success or failure of a textbook in a particular course of instruction, and in carrying out an evaluation; evaluators need to take many decisions. One is the selection of criteria for evaluation because no general list of criteria is perfect. The evaluation criteria may vary, depending on the specific circumstances of teaching and learning contexts. Many useful approaches and checklists for evaluation criteria have been proposed by McGrath (2002) and Tomlinson (2003), etc., which vary according to particular ELT contexts. Evaluators can choose from the available checklists for their evaluation, or they can select their own criteria to reflect the priorities of their own specific teaching and learning contexts. There are different tools in textbook evaluation including questionnaire, interview, checklist, observation and test. From among them, checklists can play an important role in evaluating books especially in ESP courses to decide if a book is suitable in different aspect to continue its use, discontinue it, or to use another book, or modify it and use supplementary materials. One major advantage of using the checklist approach is that it can provide a economic and systematic way to ensure all relevant items are considered for evaluation (McGrath, 2002). Checklist is a good channel to make different opinions of evaluators explicit. When opinions are explicitly shown based on checklists, they can allow for easy comparison of different sets of textbook materials, and thereby facilitate decision-making (McGrath, 2002). 


\subsection{Types of Evaluation}

Evaluations can generally be classified in two categories. Predictive evaluation as the first type, according to Ellis, can be carried out in two principal ways. One involves teachers relying on evaluations carried out by experts specializing in textbook evaluation. However, the criteria for these evaluations tend to be inexact and implicit, meaning the experts tend to evaluate textbooks for general purposes. Therefore, teachers should be careful when they use the results of these evaluations. Alternatively, teachers can carry out their own predictive evaluations by making use of various checklists and guidelines available in the literature (Çakir, 2004). Retrospective evaluation as the second type is carried out while a textbook is in use (whilst-use evaluation) or after it has been used (post-use evaluation). It is often more objective and reliable as it is based on user feedback. Such an evaluation provides information that can be used to determine whether the material is worth using. McGrath (2002) advocates this type of evaluation, stating that the most secure basis for the decision to select which textbook is used, is to try it with the learners for whom it is intended, and to get feedback from them.

\subsection{Purposes of Materials Evaluation}

Materials evaluation could have many purposes. However Akin and Guceri (2001) pointed to the main ones. They stated that there were four purposes of the materials evaluation as follows:

1. To identify how successful were the materials used in the classroom.

2. To examine whether the materials fulfilled the prescribed course objectives.

3. To examine the extent to which materials permitted students to achieve the learning objectives.

\section{METHOD}

\subsection{Participants}

To conduct the study, 2 Iranian EFL experts who had PhD degree in English were chosen. One of them was book editor with many years' experience in this regard and the other one was a course design specialist who had valuable experiences in this manner. In addition, 30 English learners were selected to participate in this study. They were the staffs of Export Development Bank of Iran who had participated in training courses of the bank wishing to improve their English for Banking Purposes. These learners had an acceptable general 
English proficiency (upper-intermediate) who were between 30 to 55 years old with 5 to 25 years' experience in the said bank.

\subsection{Instruments}

In order to evaluate the quality of the designed textbook, two research tools were used namely interview and questionnaire.

\subsubsection{Interview}

In order to obtain the experts' viewpoints about the quality of the designed book, a sevenquestion interview was developed by the researchers and then was piloted to a small sample to ensure its reliability. Meantime, such questions were also reviewed by some language experts to ensure its validity. The questions aimed to obtain the experts' evaluation about the contents and materials, topics, language skills, activities and tasks as well as physical appearance of the book.

\subsubsection{Questionnaire}

In order to obtain the staffs 'evaluation about the quality of the book, a questionnaire was developed by the researchers containing 50 questions including content, language skills/ subskills and physical appearance and content pages of the textbook. The items were designed on a Five-Point Likert scale of frequency, in which 1: strongly agree 2: agree 3: undecided 4: disagree 5: strongly agree. The validity of the questionnaire was ensured through reviewing by some language experts and its reliability was insured by running a cronbach alpha.

\subsection{Materials}

English for bankers is the name of the book designed by EDBI's English language specialists based on a needs analysis from EDBI's staffs, which is supposed to be evaluated by language experts, and staffs of the said bank.

\subsection{Procedure}

The present study was conducted in five phases. In the first phase, the book was evaluated before the course and teaching the designed book to learners. In this step, two experts were interviewed about the quality of the book as stipulated in "instruments" of the research. In the second phase, based 
on the results obtained through interview with language experts, most of the requested modifications were conducted to enrich the quality of the second draft of course book. In the third phase, the second draft of book was taught to the learners at EDBI for 48 hours in 24 sessions during 8 weeks in educational center of EDBI. In the fourth phase, the book was evaluated after the course when the staffs had been trained by the second draft of the designed book. In this step, 30 staffs as the learners of the course evaluated the book through a set of questionnaire as stipulated in "Instruments" of the research. Finally, in the fifth phase, most of alternations proposed by the learners were made for enriching the quality of the book as well as publishing the final draft of the book (the third draft).

\section{DATA ANALYSIS}

Based on the qualitative data obtained from the experts through interview and the quantitative and qualitative data obtained from the learners through questionnaire, the findings are analyzed as follows.

\subsection{Analysis of the Interview}

\section{How is your overall evaluation of the designed book?}

The experts approved that this book was designed and developed according to the staffs' needs and the materials were relevant to the designed syllabus. They also believed that the designed book could help the staffs in meeting their language needs at bank. Although they had positive attitude toward the designed book in general, they emphasized on the necessity of some editions including misspelling and ungrammatical use of some sentences. They also believed that the writer should have followed either British - English style or American - English style through the whole book. They also advised that a glossary should have been added in order to promote the quality of the book and making it easier for learners to use it at their work place.

\section{How do you evaluate the topic of the units of the book?}

The editor and the course design specialist believed that the topics were all about international banking affairs and wholly relevant to the staff's needs. They expressed their confirmation in this manner because they thought that the topics could help the staffs learn English meaningfully and in a real like environment. They felt that the topic could be motivating and interesting to the learners. However, they suggested some more topics to be added to the existing materials such as "debit and credit card" to make the source more comprehensive.

\section{How do you evaluate the contents and materials of the book?}


They approved the relevancy of the book to English for banking course and language needs of staffs. They believed that the book was realistic and could be appealing to the learners. However, they suggested that it would be better if the materials would be sequenced based on complexity, i.e., from easy to more difficult. They thought that the materials were suitable for teaching and learning purposes and could also help the staffs improve their language proficiency. However, they had some hesitancy whether the language level of the book could be in conformity with the language level of the learners (staffs).

\section{How do you evaluate the activities and tasks of the book?}

They praise using individual, pair and group work activities in different situations which could help learners learn English in a communicative manner. However, they suggested that more exercises could be mad for the new vocabulary of each unit.

\section{How do you evaluate use of all four skills in the book?}

The experts believed that all four skills had been taken into considerations in the book but not with an equal frequency. They thought listening skills had less been taken into considerations in comparison with other skills. They believed that the new vocabularies were used in realistic contexts, however, they thought more new words could be introduced for each topic. They also suggested that some more exercises for grammar could be added to each unit which could help the learners use language more accurately.

\section{How do you evaluate the physical appearance of the book?}

The experts approved the size and organization of the book. However they believed that the cover page could be more illustrative making the manual more attractive to the readers.

\subsection{Analysis of the Questionnaire}

\section{A. Overall evaluation}

1: $\underline{\mathrm{SD}}$ (strongly disagree) 2: $\underline{\mathrm{D}}$ (disagree) 3: NS (not sure) 4: $\underline{\mathrm{A}}$ (agree) 5: $\underline{\mathrm{SA}}$ (strongly agree).

\begin{tabular}{|l|r|r|r|r|r|r|}
\hline Overall evaluation & Percent & SD & D & NS & A & SA \\
\hline $\begin{array}{l}\text { 1 The topics and contents of the } \\
\text { textbook are relevant to my } \\
\text { language needs at my workplace. }\end{array}$ & Percent & 0 & 0 & 0 & 33 & 67 \\
\hline
\end{tabular}




\begin{tabular}{|c|c|c|c|c|c|c|}
\hline $\begin{array}{l}\text { 2. The book can be a good source } \\
\text { for me in performing my } \\
\text { international banking affairs. }\end{array}$ & Percent & 0 & 0 & 9 & 36 & 55 \\
\hline $\begin{array}{l}\text { 3. The contents of the text-book } \\
\text { meets my language needs at my } \\
\text { workplace. }\end{array}$ & Percent & 6 & 6 & 12 & 49 & 27 \\
\hline $\begin{array}{l}\text { 4. The contents of the text-book } \\
\text { matches the specifications of the } \\
\text { syllabus. }\end{array}$ & Percent & 0 & 3 & 18 & 46 & 33 \\
\hline $\begin{array}{l}\text { 5. The book covers a variety of } \\
\text { topics from different sections of the } \\
\text { bank. }\end{array}$ & Percent & 9 & 15 & 15 & 36 & 25 \\
\hline $\begin{array}{l}\text { 6. The language level of the book is } \\
\text { relevant to my language level. }\end{array}$ & Percent & 9 & 12 & 24 & 30 & 25 \\
\hline $\begin{array}{l}\text { 7. The textbook raises learners' } \\
\text { interest to continue learning } \\
\text { English. }\end{array}$ & Percent & 9 & 12 & 30 & 27 & $\underline{22}$ \\
\hline $\begin{array}{l}\text { 8. The book includes sufficient and } \\
\text { interesting activities and tasks. }\end{array}$ & Percent & 6 & 12 & 27 & 30 & $\underline{25}$ \\
\hline $\begin{array}{l}\text { 9. What needs improving regarding } \\
\text { the overall evaluation of the } \\
\text { textbook? }\end{array}$ & & & & & & \\
\hline
\end{tabular}

Based on the above table, almost all the staffs believed that the contents of the textbook was relevant to their language needs and it could be very helpful in meeting their needs while performing their banking affairs. They also believed that it was in conformity with specifications of the syllabus. Moreover, the staffs thought that the book could be a good source in their work place, which could be available while performing their banking affairs. They approved that it covered different topics from different sections of the bank, which could raise their interests in learning English. Concerning language level of the book, there were different distributions in their responses. While 55 percent of staffs agreed that the language level of the book was relevant to their language level, 21 percent disagreed and 24 percent were not sure about it. Based on the only open-ended question in this part, most of staffs believed that the book lacked a glossary, which could be very helpful in learning the vocabularies as well as saving their time.

\section{B. Topics}

1: $\underline{\mathrm{SD}}$ (strongly disagree) 2: $\underline{\mathrm{D}}$ (disagree) 3: $\underline{\mathrm{NS}}$ (not sure) 4: $\underline{\mathrm{A}}$ (agree) 5: $\underline{\mathrm{SA}}$ (strongly agree).

\begin{tabular}{|l|r|r|r|r|r|r|}
\hline Topics & Percent & SD & D & NS & A & SA \\
\hline
\end{tabular}




\begin{tabular}{|l|r|r|r|r|r|r|}
\hline $\begin{array}{l}\text { 10. The topics of textbook are } \\
\text { relevant to international banking } \\
\text { affairs. }\end{array}$ & Percent & 6 & 9 & 15 & 37 & 33 \\
\hline $\begin{array}{l}\text { 11. The topics of the book are } \\
\text { realistic and appealing to me. }\end{array}$ & Percent & 0 & 3 & 12 & 33 & 52 \\
\hline $\begin{array}{l}\text { 12. The topics of the lessons are } \\
\text { linked appropriately. }\end{array}$ & Percent & 3 & 6 & 18 & 43 & 30 \\
\hline $\begin{array}{l}\text { 13. The topics of the lessons help } \\
\text { me express myself. }\end{array}$ & Percent & 6 & 9 & 33 & 37 & 15 \\
\hline $\begin{array}{l}\text { 14. The topics cause independent } \\
\text { thinking and active learning. }\end{array}$ & Percent & 9 & 12 & 30 & 27 & 21 \\
\hline $\begin{array}{l}\text { 15. What needs improving } \\
\text { regarding the topics of the } \\
\text { textbook? }\end{array}$ & & & & & \\
\hline
\end{tabular}

Based on the above table, it is apparent that the staffs had positive attitudes toward the topics of the book believing that the topics were realistic and appealing and could help them in active learning and expressing themselves in real situations. They also approved the relevancy of topics to international banking affairs. Based on the open-ended question of this part, the staffs felt that more topics could be added such as corresponding relation of banks or Finance and Refinance to enrich the quality of the book.

\section{Activities and tasks}

1: $\underline{\mathrm{SD}}$ (strongly disagree) 2: $\underline{\mathrm{D}}$ (disagree) 3: NS (not sure) 4: $\underline{\mathrm{A}}$ (agree) 5: $\underline{\mathrm{SA}}$ (strongly agree).

\begin{tabular}{|l|r|r|r|r|r|r|}
\hline Activities and tasks & Percent & SD & D & NS & A \\
\hline $\begin{array}{l}\text { 16. There are enough activities and } \\
\text { tasks for listening skill in this book. }\end{array}$ & Percent & 12 & 18 & $\underline{22}$ & 27 & 21 \\
\hline $\begin{array}{l}\text { 17. There are enough activities and } \\
\text { tasks for speaking skill in this book. }\end{array}$ & Percent & 3 & 3 & 42 & 34 & 18 \\
\hline $\begin{array}{l}\text { 18. There are enough activities and } \\
\text { tasks for reading skill in this book. }\end{array}$ & Percent & 6 & 6 & 21 & 40 & 27 \\
\hline $\begin{array}{l}\text { 19. There are enough activities and } \\
\text { tasks for writing skill in this book. }\end{array}$ & Percent & 3 & 9 & 24 & 43 & 21 \\
\hline $\begin{array}{l}\text { 20. The instructions in tasks and } \\
\text { activities are clear. }\end{array}$ & Percent & 0 & 3 & 18 & 54 & 25 \\
\hline $\begin{array}{l}\text { 21. The activities help me use } \\
\text { language meaningfully. }\end{array}$ & Percent & 9 & 12 & 24 & 30 & 25 \\
\hline
\end{tabular}




\begin{tabular}{|l|l|l|l|l|l|l|}
\hline $\begin{array}{l}\text { 22. The activities incorporate } \\
\text { individual, pair and group work. }\end{array}$ & Percent & 3 & 6 & 18 & 48 & 25 \\
\hline $\begin{array}{l}\text { 23. What needs improving } \\
\text { regarding the activities and tasks? }\end{array}$ & \multicolumn{1}{l}{} \\
\hline
\end{tabular}

Based on the above table, the majority of the staffs were consent with the clear instructions of tasks and activities, which incorporated individual, pair and group work. Such tasks and activities help them use language meaning fully. However, concerning the sufficiency of the activities, there were distributions among different skills in their responses i.e. 48 percent approved the matter for listening tasks, 58 percent for speaking tasks, 67 percent for reading activities and 84 percent for writing activities. Based on the only open-ended question of this part, most of staffs asked to include more tasks and activities for speaking skill because they thought they needed more practice to improve their speaking skill.

\section{Activities and tasks}

1: $\underline{\mathrm{SD}}$ (strongly disagree) 2: $\underline{\mathrm{D}}$ (disagree) 3: $\underline{\mathrm{NS}}$ (not sure) 4: $\underline{\mathrm{A}}$ (agree) 5: $\underline{\mathrm{SA}}$ (strongly agree).

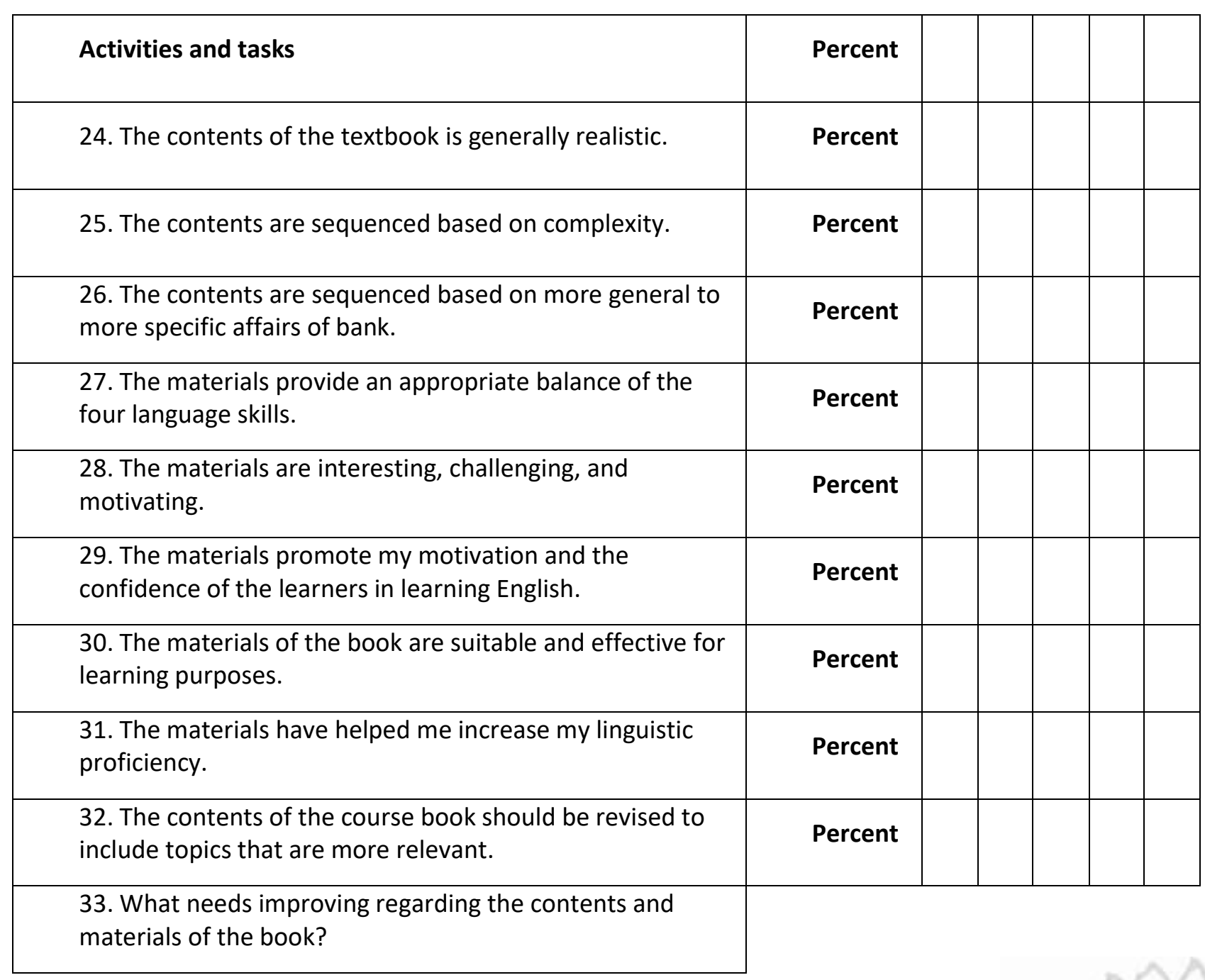


Based on the above table, the majority of the staffs believed that the contents and materials of the book was realistic, challenging and motivating and was suitable and effective for learning process. They also agreed that the materials were useful in promoting their confidence in learning and in increasing their linguistic proficiency. However, most of them disagreed about sequencing the contents of the book based on complexity because they thought the contents were sequenced from more general to more specific affairs of the bank. Meantime, there were different viewpoints with regard to providing an appropriate balance of the four language skills. 52 percent of learners agreed, 24 percent disagreed and 24 percent were not sure. The same happened for the necessity of the revision of the book as 18 percent agreed that the book needed modifications, 46 percent disagreed and 36 percent were not sure. Based on the only open ended question of this part, the majority of staffs asked for providing a glossary at the end of the book and adding some more contents such as samples of banking contracts.

\section{E. Language skills/subskills}

1: $\underline{\mathrm{SD}}$ (strongly disagree) 2: $\underline{\mathrm{D}}$ (disagree) 3: NS (not sure) 4: $\underline{\mathrm{A}}$ (agree) 5: $\underline{\mathrm{SA}}$ (strongly agree).

\begin{tabular}{|c|c|c|c|c|c|c|}
\hline Language skills/subskills & Percent & SD & D & NS & A & SA \\
\hline $\begin{array}{l}\text { 34. All four skills are adequately } \\
\text { covered. }\end{array}$ & Percent & 6 & 9 & 15 & 37 & 33 \\
\hline $\begin{array}{l}\text { 35. All four skills are introduced in } \\
\text { motivating and realistic contexts. }\end{array}$ & Percent & 3 & 3 & 12 & 48 & 34 \\
\hline $\begin{array}{l}\text { 36. The vocabulary load of the book } \\
\text { is suitable. }\end{array}$ & Percent & 3 & 6 & 18 & 43 & 30 \\
\hline $\begin{array}{l}\text { 37. Key words are efficiently } \\
\text { repeated and used across the book. }\end{array}$ & Percent & 3 & 6 & 21 & 43 & 27 \\
\hline $\begin{array}{l}\text { 38. The new vocabulary words are } \\
\text { presented at an appropriate rate } \\
\text { enabling me to retain them. }\end{array}$ & Percent & 6 & 9 & 24 & 36 & 25 \\
\hline $\begin{array}{l}\text { 39. The vocabulary introduced in this } \\
\text { book is applicable. }\end{array}$ & Percent & 3 & 3 & 6 & 49 & 39 \\
\hline $\begin{array}{l}\text { 40. The grammar is indirectly } \\
\text { introduced in motivating and } \\
\text { realistic contexts. }\end{array}$ & Percent & 3 & 3 & 12 & 49 & 33 \\
\hline $\begin{array}{l}\text { 41. Writing activities are suitable in } \\
\text { terms of difficulty, interest, and } \\
\text { amount of guidance. }\end{array}$ & Percent & 6 & 6 & 27 & 36 & 25 \\
\hline $\begin{array}{l}\text { 42. The reading passages are } \\
\text { enough, interesting and of } \\
\text { appropriate length. }\end{array}$ & Percent & 9 & 9 & 24 & 37 & 21 \\
\hline
\end{tabular}

43. What needs improving regarding the language skills/subskills of the book? 
The majority of staffs approved that all four skills were adequately covered and were introduced in realistic contents. They were satisfied with the load of vocabulary and its applicability and thought that the key words were efficiently repeated and recycled across the book. They also agreed that the grammar was indirectly introduced in motivating and realistic contexts. However they disagreed that the reading passages were enough and of appropriate length. Based on the open-ended question of this part, most of them believed that since writing is the most needed skill in performing their banking affairs, more emphasis should be on writing skills and more contents should be added in this regard such as banking and business correspondence.

\section{F. Physical appearance and content pages}

1: $\underline{\mathrm{SD}}$ (strongly disagree) 2: $\underline{\mathrm{D}}$ (disagree) 3: NS (not sure) 4: $\underline{\mathrm{A}}$ (agree) 5: $\underline{\mathrm{SA}}$ (strongly agree).

\begin{tabular}{|l|r|r|r|r|r|r|}
\hline $\begin{array}{l}\text { Physical appearance and content } \\
\text { pages }\end{array}$ & Percent & SD & D & NS & A & SA \\
\hline $\begin{array}{l}\text { 44. The book size is suitable to } \\
\text { carry. }\end{array}$ & Percent & 3 & 3 & 15 & 42 & 37 \\
\hline $\begin{array}{l}\text { 45. The cover sheet is attractive. } \\
\text { 46. The paper quality is good. }\end{array}$ & Percent & 3 & 9 & 21 & 37 & 30 \\
\hline $\begin{array}{l}\text { 47. The organization (pictures, } \\
\text { white space and font size) in the } \\
\text { book is appropriate. }\end{array}$ & Percent & 6 & 12 & 30 & 28 & 24 \\
\hline $\begin{array}{l}\text { 48. The aims and audience are } \\
\text { clearly stated. }\end{array}$ & Percent & 9 & 12 & 30 & 28 & 21 \\
\hline $\begin{array}{l}\text { 49. There is a clear overview of } \\
\text { content page. }\end{array}$ & Percent & 3 & 6 & 21 & 46 & 24 \\
\hline $\begin{array}{l}\text { 50. What needs improving } \\
\text { regarding physical appearance and } \\
\text { content pages? }\end{array}$ & & & & & & \\
\hline
\end{tabular}

The majority of staffs were consent about the book size, cover sheet, organization of materials and the clear overview of the content page. However, they had different viewpoints with regard to stating clearly the aims and audience. Based on the open-ended question of this part, some of staffs felt that it would be better if more illustrations would be used in the book.

\section{RESULTS AND DISCUSSIONS}

To sum up the results of this study, the research questions will be restated and their answers will be provided as follows. 
RQ1. How do language experts and EDBI's staffs assess the quality of the book?

Both language experts and learners of ESP course had positive attitude towards the content, topics, tasks and activities, langue skills/subskills and physical appearance of the book. They believed that the contents of the book were relevant to the langue needs of EDBI staffs and could help them express themselves meaningfully. They also thought that the designed book could be a good source for the staffs at their work place, which, to very much extent, met their language needs.

RQ2. What recommendations do language experts and EDBI's staffs make for the improvement of the textbook?

In spite of the fact that language experts and EDBI's staffs generally approved the quality of the book, they recommended that the book needed some modifications and additions of some more materials, which is summarized as follows.

1. Adding a glossary, which can help learners, look for the unknown vocabulary easily and save their time.

2. Editing misspelling and grammatical use of some sentences.

3. Following either British-English style or American-English style throughout the book.

4. Adding more topics and units to the books.

5. Adding more materials to writing skills especially for banking and business correspondences.

6. Providing more activities and tasks for the new vocabulary and speaking skill of each unit.

7. Using more illustrations to make the physical appearance of the book more attractive.

\section{CONCLUSIONS AND IMPLICATIONS}

An English language textbook for banking purposes had already been designed based on the language needs of EDBI staffs for further use of it in ESP training courses of the bank. To ensure about the validity and quality of the textbook, it was evaluated by 2 language experts through an interview before the course and 30 bank's staffs as learners of the course through a set of questionnaire after the course. The findings of the study indicated that both language experts and EDBI's staffs had positive attitudes toward the materials, topics, activities and tasks, language skills and physical appearance of the text book. However, they asked for some modifications and addition of new materials to the existing ones. In fact, the results of the instruments became a basis to further improvement and correction until the draft would be finalized as a ready use material. Therefore, the required modifications and alternations were conducted based on their evaluations to make the product high valid and high practical with a potent effect.

The findings of the present study bear significant implications for materials developers and teachers especially in applying appropriate materials in ESP courses and evaluating the textbooks in the related studies. Like any other research, the present study suffered from some limitations which could make it conductive to further investigations. First, the current research has been conducted in Export Development Bank of Iran (EDBI), thus, the results are restricted to the occupational language needs of this bank with a limited number of participants. This research can be replicated in other banks with a larger sample. Second, the researchers could not conduct a formative evaluation due to large amount 
of materials to be taught within a limited time for each session. Thus, further study can be investigate conducting both formative and summative evaluation.

\section{References}

Acar, A. (2006). Designing an effective ELT primary school textbook model by means of evaluating the primary school ELT textbooks.

Albertus Lalaun \& Mansye Sekewael (2017). Designing English Specific Purpose Materials for the Students in Accounting Program at Politeknik Negeri AmbonPoliteknik Negeri Ambon.

Alemi, M. \& Mesbah, Z., (2013). Textbook evaluation based on the ACTFL standards: The case study of Top Notch series. The Iranian EFL Journal.

Awasthi, R. J., (2006). Textbook and its evaluation. Journal of NELTA.

Bennett, J. (2003) Evaluation Methods in Research. London: Continuum.

Byrd, P., (2001). Textbooks: Evaluation for selection and analysis for implementation.

Cang Trung Nguyen March, (2015). An Evaluation of the Textbook English 6: A case study from secondary schools in the Mekong Delta Provinces of Vietnam.

Creswell, J.W., (2014). Research design: Qualitative, Quantitative and Mixed Methods Approaches. (4th edn). Thousand Oaks. London: Sage Publications.

Erozan F., (2005). Evaluating the Language Improvement Courses in the Undergraduate ELT Curriculum at Eastern Mediterranean University: A Case Study.

Hadi Salehi1, Zahra Khadivar1 \& Mahmood Mehrabi1 (2015), Evaluation of an ESP Medical Textbook: Instructors and Learners' Perceptions in Focus.

Hall, I. \& Hall, D. (2004). Evaluation and Social Research: Introducing Small-scale Practice in English Language Teaching. New York: Palgrave Macmillan.

Holmes, J. (2008) 'Feedback -A Systems Approach to Evaluation and Course Design.

Kiely, R. \& Rea-Dickins, P. (2005). Program Evaluation in Language Education.

Litz, R. A. D., (2002). Textbook evaluation and ELT management: A South Korean Case Study.

Jahangard, A, (2007). Evaluation of EFL materials taught at Iranian Public High Schools.

Maryam Azarnoosh, Maryam Ganji (2014). ESP book evaluation: A case of management course Book

Maryam, D. T. \& Sara, H. (2014). Evaluation of ESP textbooks: Evidence from ESP textbook of computer engineering major.

McGrath, I., (2002). Materials Evaluation and Design for Language Teaching. Edinburgh: Edinburgh University Press. 
McGrath, I., (2002). Teachers' and learners' images for course books. https://doi.org/10.1093

Mohammadi, S. M. \& Moghadam, A. S. (2015). A comparative evaluation of two ESP textbooks for students of engineering: Merits and demerits.

Norris, J. M. (2008). Validity Evaluation in Language Assessment. Frankfurt: Peter Lang.

Richards, J. C. (2001). The role of textbooks in a language program. Cambridge University Press.

Saeid Najafi Sarem1, Hadi Hamidi2, Rezvan Mahmoudie (2013), A Critical Look at Textbook Evaluation: A Case Study of Evaluating an ESP Course-Book: English for International Tourism

Skierso, A., (2001). Textbooks selection and evaluation, in Celce-Murcia, M. (ed.). Teaching English as a Second or Foreign Language. Boston

Tomlinson, B. (2003). Materials evaluation. In: Tomlinson, B. ed. Developing Materials for Language Teaching.

\section{ABOUT THE AUTHORS}

\section{Mohammad-reza Takrousta}

Department of Foreign Languages, Central Tehran Branch, Islamic Azad University, Tehran, Iran.

Email: mtakrosta@yahoo.com.

Orcid: https://orcid.org/0000-0002-3362-4528

\section{Parviz Behrouzi}

Department of Foreign Languages, Central Tehran Branch, Islamic Azad University, Tehran, Iran.

Email: pbehrou@gmail.com.

Orcid: https://orcid.org/0000-0001-6217-3909

\section{Sholeh Kolahi}

Department of Foreign Languages, Central Tehran Branch, Islamic Azad University, Tehran, Iran.

Email: pbehrou@gmail.com.

Orcid: https://orcid.org/0000-0001-6058-7470 